\title{
Pengembangan Aplikasi Mobile Learning untuk Pertolongan Pertama
}

\author{
Sumei Chai \\ Technopreneurship \\ Fakultas Sosial dan Ekonomi \\ Surya University \\ technopreneurship@surya.ac.id
}

\author{
Odi Akhyarsi \\ Technopreneurship \\ Fakultas Sosial dan Ekonomi \\ Surya University \\ technopreneurship@surya.ac.id
}

\author{
Heru Wijayanto \\ Technopreneurship \\ Fakultas Sosial dan Ekonomi \\ Surya University \\ technopreneurship@surya.ac.id
}

\begin{abstract}
Abstrak- Pengetahuan dan pelatihan mengenai Pertolongan Pertama merupakan hal yang terbilang penting. Oleh karena itu, diperlukan fasilitas yang lebih mudah bagi masyarakat yang tertarik untuk mengikuti pelatihan ini. Mengingat banyak masyarakat yang terhalang jarak dan waktu untuk mempelajarinya, maka dilakukanlah pengembangan metode pelatihan dengan memanfaatkan berbagai teknologi yang ada saat ini sehingga persoalan jarak dan waktu serta informasi dapat terselesaikan. Pengembangan yang dilakukan memungkinkan peserta melaksanakan proses pelatihan secara mobile.
\end{abstract}

Kata kunci: : mobile learning, pertolongan pertama, aplikasi, pelatihan, sertifikasi, e-certificate

\section{PENDAHULUAN}

Di awal abad ke dua puluh satu, terjadi inovasi menarik dalam metode belajar dan mengajar. Masyarakat mulai memanfaatkan berbagai teknologi yang telah ditemukan sebelumnya seperti, komputer, telepon genggam, internet dan perangkat lainnya yang telah disempurnakan sehingga dapat dimanfaatkan untuk melakukan proses belajar dan mengajar yang lebih efektif dan efesien. ${ }^{[1]}$

Pada awalnya, masyarakat dikenalkan dengan konsep $e$ learning (electronic learning).E-learning sendiri didefinisikan sebagai penggunaan komputer untuk melaksanakan proses belajar dan mengajar yang biasa dilakukan di sekolah atau kursus tanpa dibatasi jarak. Pada awal perkembangannya, banyak masyarakat mengira dengan menggunakan metode ini dapat menghilangkan interaksi langsung antar manusia yang akan berdampak buruk pada psikologisnya. Namun, seiring berkembangnya teknologi, $e$ learning dapat memanfaatkan smartphone, dan tablet yang dapat digunakan di kelas, serta mengabungkan desain interaktif yang membuat menarik dengan penyampaian pembelajaran yang tepat guna. ${ }^{[2]}$

Penggunaan prasarana smartphone ataupun tablet dalam proses e-learning mulai dikenal dengan istilah mobile learning. Mobile learningmerupakanmetode pembelajaran yang memanfaatkan teknologi informasi dan komunikasi. Tujuanprogram mobile learning yakni,untuk mempermudah belajar siswadimana pun dan kapanpun. Karena memiliki karakteristik yang praktis dibawa kemanapun, maka mobile learning memiliki ketertarikan tersendiri. Dengan mobile yang terkoneksi dengan internet, maka pengguna bisa menjelajah dunia manapun termasuk dalam mencari bahan ajar yang mendukung bagi pembelajaran. Pertimbangan adanya keefektifan belajar berbasis mobile menawarkan pengembangan model yang mutakhir guna membantu siswa maupun pendidik untuk lebih mudah dalam pembelajaran minimal dapat memberikan motivasi belajar siswa. ${ }^{[3]}$

Bidang medis duniatelah banyak mengembangkan metode pembelajaran baru ini, salah satunyadengan membuat berbagai aplikasi mobile yang menarikdan dapat banyak membantu, seperti, Hip Pro Iii Another Impressive Specialist Nova Anatomy App, yang merupakan kumpulan cara untuk menghilangkan bekas jerawat, ada pula yang sepertipain scale, yang mengajarkan anak-anak pelajaran sederhana mengenai dunia medis.

Berdasarkan hasil studi sebelumnya terhadap hampir 43.700 aplikasi medis yang tersedia di toko aplikasi iTunes Apple, hanya 54\% yang "sungguh-sungguh" merupakan aplikasi kesehatan. 69\% ditargetkan untuk konsumen dan pasien sedangkan $31 \%$ untukdigunakan oleh dokter. Sebagian besar aplikasi kesehatan konsumen yang "mudah digunakan namun tidak banyak memberikan informasi" menurut laporan IMS. ${ }^{[4]}$

Pengetahuan dan pemahaman berbagai cara untuk menangani kegawatdaruratan dasar merupakan hal yang sangat penting. Namun, masih minim orang yang memiliki pengetahuan, pemahaman dan keterampilan ini. Oleh karena itu, banyak pihak seperti, pemerintah, organisasi indepen, aktivis, bahkan perusahaan swasta, yang berusaha menyiasati masalah ini. Salah satunya adalah dengan memanfaat teknologi mobile learning yang sedang berkembang pesat. Organisasi perhimpunan nasional yang bergerak dalam bidang sosial kemanusiaan dari berbagai negara telah banyak mengembangkan aplikasi mobile learning untuk pertolongan pertama seperti, PMI First Aid, First Aid by America Red Cross, First Aid by Kosova Red Cross, dan First Aid by British Red Cross.

Pembelajaran yang telah ditawarkan aplikasi tersebut belum menyediakan pelatihan pertolongan pertama yang lebih lanjut dengan basis mobile learning. Aplikasi tersebut masih menawarkan pelatihan yang langsung bertatap muka. 
Pada studi sebelumnya, dikatakan bahwa, pelatihan berbasis komputer memainkan peran penting dan efektif. Pendidikan berbasis Internet dapat membantu membuat materi pendidikan perawatan kritis seperti deskripsi dari teknik CPR terbaru lebih mudah diakses oleh orang banyak. Pelatihan berbasis komputer tidak menakutkan bisa lebih fleksibel untuk pelajar, yaitu, dapat tersedia kapan dan di mana pelajar ingin hal itu terjadi. Hal ini akan meningkatkan jumlah orang yang telah terlatih sehingga akan juga berdampak pada jumlah orang yang dapat tertolong. ${ }^{[5]}$

Pada 1997, sebuah kelompok telah menya-dari pentingnya pelatihan pertolongan pertama. Disadari bahwa pelatihan harus senantiasa dikembangkan. Bahkan pada tahun tersebut, sudah terdapat sebuah situs Web World Wide yang merancang draft pembelajaran Pertolongan Pertama. ${ }^{[8]}$

Sebuah komite CPR mengatakan bahwa 1.950 siswa dan 240 anggota masyarakat dari tahun 1996 hingga 2009 memiliki sertifikat CPR. Organisasi tersebut mengatakan bahwa diperlukan lebih banyak orang yang tersertifikasi dan diperlukan fasilitas yang lebih baik untuk mencapai hal tersebut. ${ }^{[9]}$

Pelatihan via web yang sudah dilakukan menunjukan adanya tanggapan baik pada masyarakat. Pelatihan via web ini hanya ditargetkan untuk pekerja rumah sakit. Web ini dimulai pada November 2001. Pada 2002, diketahui bahwa kunjungan terhadap web tersebut mencapai 2.736 kunjungan. Dan pada 2003 mencapai 4100 kunjungan. ${ }^{[5]}$

Mengingat pembelajaran berbasis komputer telah banyak diimplementasikan ke mobile learning maka akan lebih praktis apabila pelatihan ini dapat di terapkan pada aplikasi milik Palang Merah Indonesia, sebagai organisasi sosial kemanusiaan yang diakui di Indonesia, yang bertujuansebagaiaplikasipertolonganpertama.

\section{TINJAUAN APLIKASI PMI: FIRST AID}

\subsection{PENGENALAN APLIKASI}

Perhimpunan Nasional Palang Merah Indonesia (PMI) merupakan anggota dari Federasi Internasional Palang Merah dan Bulan Sabit Merah (IFRC) bersama dengan 186 anggota di dunia. PMI merupakan produk Sejarah Bangsa Indonesia lahir satu bulan setelah Hari Kemerdekaan RI (17 September 1945). Pertolongan pertama menjadi pelayanan khas Palang Merah di dunia dalam kegiatan-kegiatan kemanusiannya.

Berdasarkan Peraturan Kemenkes No. RI. 023/Birhub/1972, PMI dapat mengorganisir dan menyelenggarakan pelatihan dan Posko Pelatihan Pertama. Gerakan Palang Merah dan Bulan Sabit Merah memiliki karakter tersendiri yang membedakan kegiatan Pertolongan Pertama dari institusi lainnya.

Pertolongan Pertama adalah tindakan cepat untuk meringankan beban penderitaan orang yang terluka/kecelakaan yang memerlukan bantuan medis. Sementara pelaku pertolongan pertama adalah orang yang tiba di lokasi kecelakaan dan memiliki kemampuan dasar untuk pertolongan medis.

Setiap individu dapat dihadapkan pada situasi dimana ia merupakan orang pertama dan mungkin menjadi penolong di lokasi kecelakaan. Keadaan darurat ataupun kecelekaan di lingkungan kerja dapat terjadi sewaktu-waktu. Kesiapan dan keterampilan setiap individu dalam pertolongan pertama dapat membantu dalam menangani orang yang sakit dan cidera.

Keseriusan Palang Merah Indonesia ditunjukan dengan membuat sebuah aplikasi yang dapat digunakan oleh masyarakat untuk melakukan pertolongan pertama. Informasi yang diberikan secara bertahap dan mengunakan bahasa yang mudah dimengerti serta tampilan yang sederhana sehingga mudah untuk dipahami.

Aplikasi ini pertama dikenalkan pada masyarakat pada 15 Oktober 2013 dan belum pernah mengalami perbaikan hingga 5 Maret 2015. Aplikasi ini dikembangkan oleh sebuah perusahaan asal Inggris bernama 3Sided Cube yang juga mengembangkan aplikasi serupa untuk America Red Cross dan British Red Cross. Hingga saat ini, aplikasi ini hanya tersedia bagi pengguna Android dan iOS. Aplikasi ini telah di unduh lebih dari 1000 pengguna dan memperoleh rating 4,6 dari total 285 responden. 


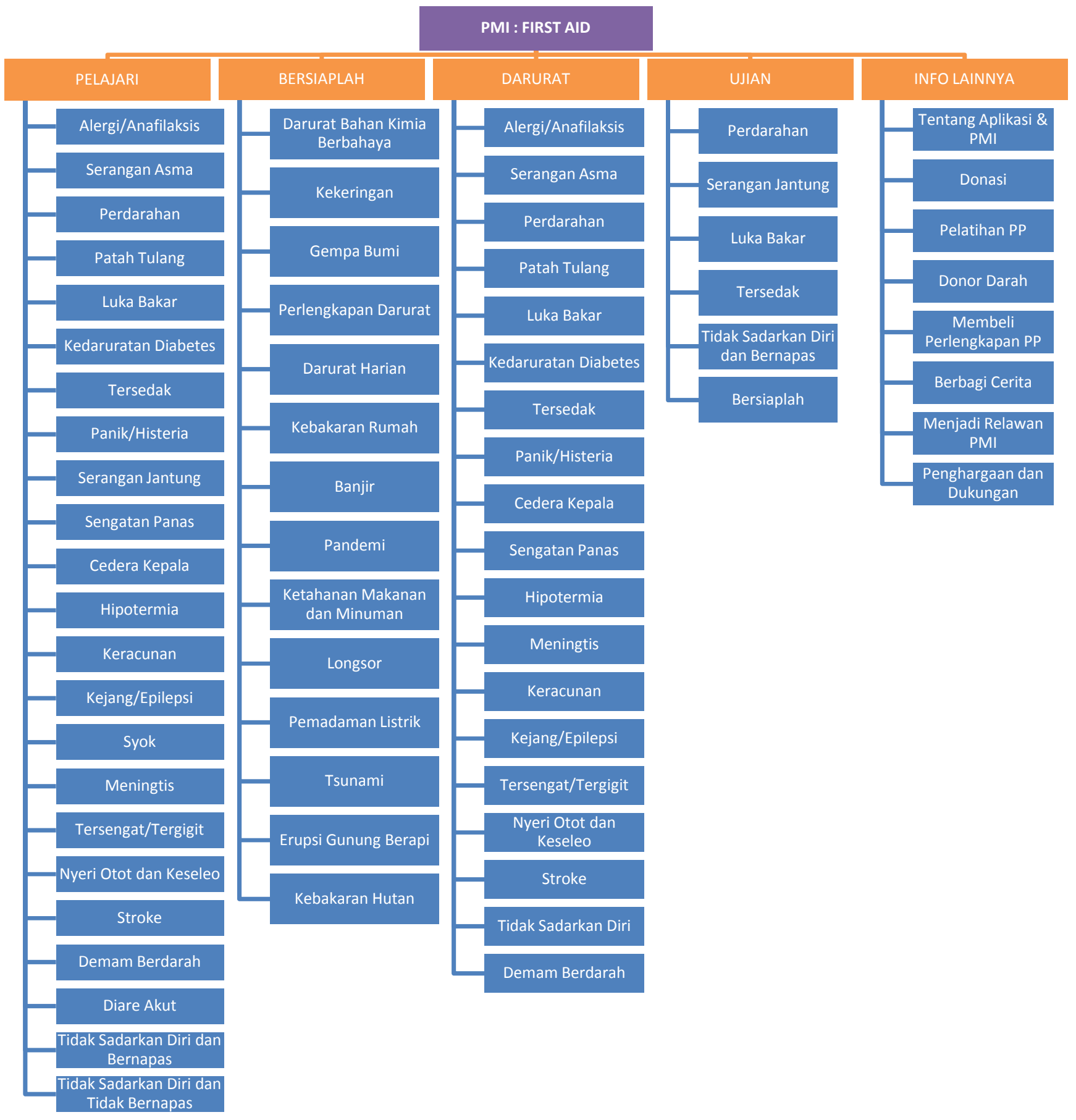

Gambar 1. Diagram:PMI First Aid Kit

\subsection{KONSEP APLIKASI}

Unsur-unsur yang terdapat pada aplikasi ini akan dijelaskan dalam peta konsep sebagai berikut Aplikasi ini dibuat dengan konsep user-friendly dengan menggunakan bahasa yang mudah dimengerti serta disain aplikasi yang mudah digunakan. Konten aplikasi ini dibuat oleh Palang
Merah Indonesia berdasarkan program pertolongan pertama sehari-hari yang disesuaikan dengan panduan pertolongan pertama Palang Merah Indonesia.

Aplikasi ini terbagi dalam 5 konten utama, yaitu, pelajari, bersiaplah, darurat, ujian dan info lainnya. Pada konten pelajari, terdapat 23 bagian yang menjelaskan berbagai 
pelajaran pertolongan pertama. Bagian ini dilengkapi gambar dan tulisan.

Pada bagian bersiaplah, terdapat 14 bagian yang menjelaskan berbagai pengetahuan yang diperlukan untuk menghindari berbagai bencana. Bagian ini dilengkapi gambar, tulisan dan berbagai tips. Lalu, pada bagian ujian, terdapat berbagai test singkat untuk menguji kemampuan pengguna setelah mempelajari berbagai hal dari konten pelajari. Pada bagian terakhir terdapat konten informasi lainnya yang merupakan bagian tambahan seperti, pengetahuan donor darah dan lokasi unit donor darah, berbagi cerita dan lainnya.

Berikut adalah beberapa gambar aplikasi PMI - First Aid saat ini :
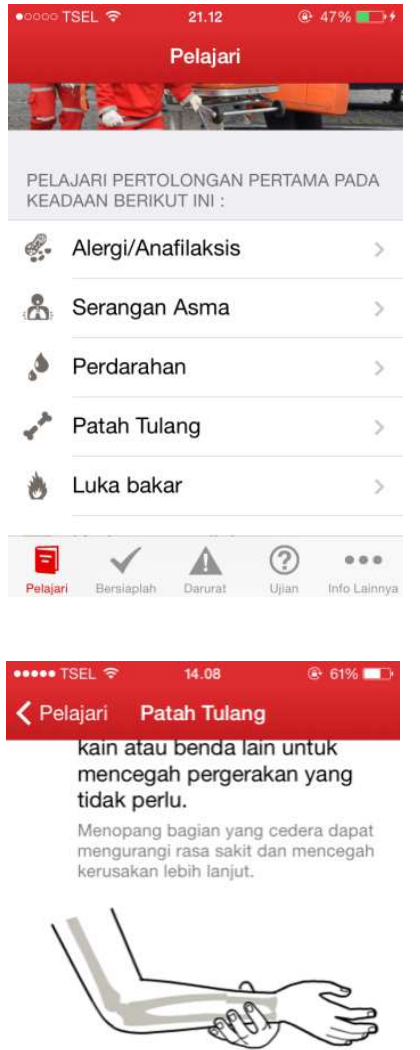

2 Jika area yang cedera terlihat remuk, sangat nyeri dan perlu dilarikan ke rumah sakit, hubungi fasilitas kesehatan terdekat atau minta seseorang

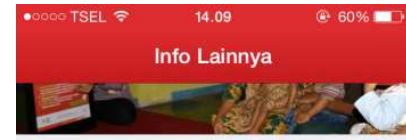

i Tentang Aplikasi \& PMI >

Rp) Donasi

Ikuti Pelatihan PP

Donor Darah

두를 Membeli Perlengkapan PP
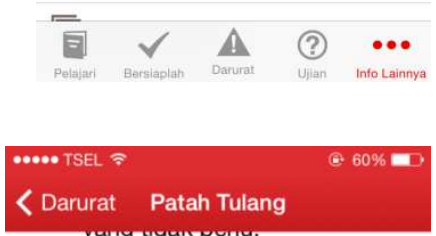

2 Jika area cedera terlihat jelasjelas hancur, sangat sakit atau perlu untuk dibawa ke rumah sakit, hubungi Fasilitas kesehatan terdekat atau Call Center PMI (021-179)

sesegera mungkin atau minta orang lain untuk membantunya.

\section{Hubungi Call Center PMI}

3 Pastikan bahwa cedera itu ditopang hingga bantuan datang.
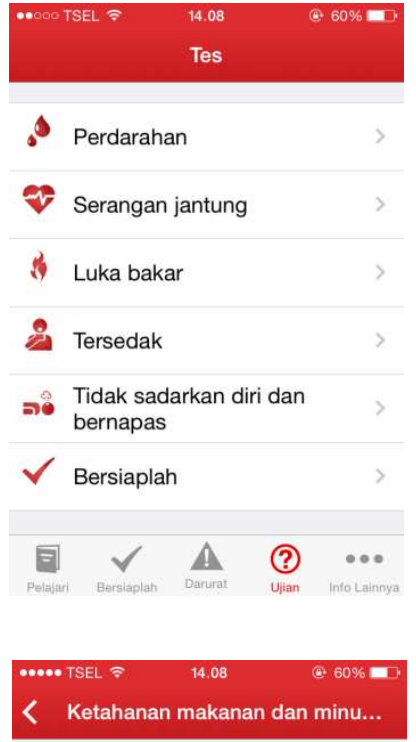

Makanan dan Minuman bisa saja tidak aman Makanan dan Minuman bisa saja tidak aman
untuk dimakan/diminum setelah kadaluarsa.

BAGAIMANA MENGOLAH AIR

1 Merebus air hingga mendidih adalah metode yang paling aman untuk membunuh bakteri dan parasit yang berbahaya.

2 Saringlah air dengan menggunakan kain yang bersih untuk menghilangkan lumpur.

3 Rebus air hingga mendidih Merebus air akan membunuh
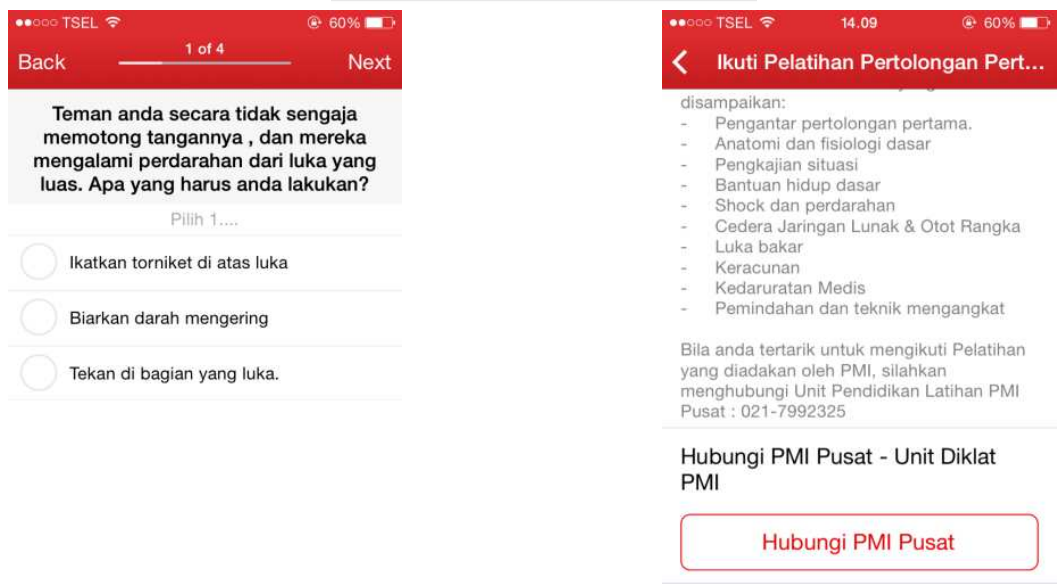

Gambar 2. Tampilan Aplikasi PMI yang Ada Saat ini 


\subsection{PERBEDAAN APLIKASI SERUPA LAINNYA}

Terdapat 3 aplikasi serupa yang dikembangkan oleh 3 Sided Cube untuk organisasi palang merah Indonesia, Amerika dan Inggris dengan nama :

- $\quad$ PMI First Aid untuk Indonesia

- First Aid by America Red Cross untuk Amerika

- First Aid by British Red Cross untuk Inggris.

Berikut pembahasan mengenai tiga aplikasi sampel:

\section{First Aid by American Red Cross}

- Dikembangkan oleh sebuah perusahan inggris bernama 3 sided cube.

- Pertama kali diperkenalkan pada 31 Mei 2012 dan telah melakukan perbaikan sebanyak $10 \mathrm{kali}$, hingga, 26 November 2014, aplikasi ini telah mencapai versi 2.1

- Telah banyak mendapat pujian dan pengakuan berbagai pihak seperti, Mashable, Appolicious, Babble.com, Complex Tech.

- Telah di unduh lebih dari 500.000 pengguna dan memperoleh rating 4,5 dari total 7060 responden.

\section{First Aid by British Red Cross}

- Dikembangkan oleh sebuah perusahan inggris bernama 3 sided cube.

- Pertama kali diperkenalkan pada 2 Desember 2011 dan telah melakukan perbaikan sebanyak 6 kali, hingga, 8 Maret 2014, aplikasi ini telah mencapai vers 2.0.2

- Telah di unduh lebih dari 100.000 pengguna dan memperoleh rating 4,7 dari total 3.371 responden.

\section{PMI - First Aid}

- Dikembangkan oleh sebuah perusahan inggris bernama 3 sided cube.

- Pertama kali diperkenalkan pada 15 Oktober 2014 dan belum pernah mengalami perbaikan.

- Hanya tersedia bagi Android dan iOS.

- Telah di unduh lebih dari 1.000 pengguna dan memperoleh rating 4,6 dari total 285 responden.

Dari ketiga aplikasi tersebut, terdapat banyak persamaan, seperti tampilan yang benar-benar menyerupai, layanan serupa, kalimat yang sama namun terjadi perbedaan bahasa, dan gambar yang digunakan. Perbedaan dijelaskan pada tabel berikut:

Tabel 1. Perbedaan Aplikasi

\begin{tabular}{|c|c|c|c|}
\hline PERBEDAAN & PMI & ARC & BRC \\
\hline Jumlah pelajaran & 23 & 22 & 18 \\
\hline Pelajaran berbeda & Demam berdarah, diare akut. & Ebola & - \\
\hline Video singkat & - & Ada & Ada \\
\hline Bahasa lain & - & Spanyol & - \\
\hline Jumlah persiapan & 14 & 20 & 15 \\
\hline Persiapan berbeda & $\begin{array}{l}\text { Drough, emergencies kit, food } \\
\text { safety, landslide, power outage, } \\
\text { volcano, wildfires. }\end{array}$ & $\begin{array}{l}\text { Hearwave, hurricane, pet } \\
\text { preparedness, tornado, water } \\
\text { safety, winter weather, drough, } \\
\text { emergencies kit, food safety, } \\
\text { landslide, power outage, } \\
\text { volcano, wildfires. }\end{array}$ & $\begin{array}{l}\text { Crowd incidents, grab bag, road } \\
\text { traffic incidents, terrorism, top } \\
\text { ten tips, travel emergencies, } \\
\text { workplace emergencies. }\end{array}$ \\
\hline Jumlah emergency & 19 & 19 & 17 \\
\hline Emergency berbeda & Heat stroke, stings/bites. & Heat stroke, stings/bites & - \\
\hline Jumlah test & 6 & 11 & 13 \\
\hline Bantuan pencarian rumah sakit & tidak & iya & iya \\
\hline
\end{tabular}

\subsection{PELATIHAN PP ONLINE}

Pada konten pelajari dan darurat terdapat keterangan "CPR (Bantuan Pernapasan) Penuh (hanya bagi mereka yang bersertifikat", disadarai bahwa untuk beberapa pertolongan, diperlukan kemampuan khusus yang terlatih.

Saat ini, PMI telah menyediakan pelatihan pertolongan pertama yang hanya tersedia bagi perusahaan atau organisasi yang tertarik dan membutuhkan. Hal ini menghambat individu yang secara indepen ingin belajar dan mendapatkan sertifikat, ataupun masyarakat yang ingin belajar namun terhalang waktu dan jarak.

Pelatihan Pertolongan Pertama online dengan memanfaatkan aplikasi yang telah ada memiliki tujuan agar lebih banyak orang yang terlatih sehingga dapat menekan akan kematian ataupun cidera berat. Selain itu juga berguna bagi pengguna sebagai ilmu pengetahuan dan juga dapat menekan biaya yang diperlukan apabila pelatihan dilaksanakan langsung.

Individu yang tertarik untuk melaksanakan pelatihan ini, nantinya harus mengisi formulir online dan memilih pelatihan yang diinginkan, serta mentransfer sejumlah uang kepada pihak PMI sebagai biaya pelatihan yang termasuk biaya perlengkapan, admin dan materi ajar. Hal tersebut akan di proses oleh pihak Unit Pendidikan dan Pelatihan PMI. Setelah itu, pelajar akan diberi akses untuk mendapatkan materi ajar serta akan dikirimkan perlengkapan Pertolongan Pertama dalam bentuk fisik ke pelajar. 
Setelah mempelajari materi ajar yang dikirimkan, maka pelajar harus mengisi ujian tertulis dan mengunggah video simulasi yang nantinya akan dinilai oleh Unit Pendidikan dan Pelatihan PMI. Apabila pelajar berhasil, maka pelajar akan memperoleh sertifikat dalam bentuk softcopy yang dapat dicetak sendiri. Aplikasi akan dilengkapi berbagai fitur penunjang seperti PocketCPR.

\section{PENGARUH PELATIHAN PP ONLINE}

\subsection{TUJUAN PELATIHAN PP ONLINE}

a. Memberikan pengetahuan dan kemampuan individu dalam teknik-teknik pertolongan pertama sesuai dengan Panduan Internasional tentang Palang Merah (International Protocol of Red Cross)

b. Menguasai tindakan-tindakan pertolongan pertama jika diperlukan, sebelum mendapatkan tindakan medis lebih lanjut untuk menghindari atau mengurangi dampak yang tidak diinginkan sebagai akibat dari kecelakaan.

c. Pertolongan Pertama memberikan kemampuan yang sesuai kala peralatan medis yang sesuai tidak dapat ditemukan di lokasi kejadian.

d. Memberikan kepercayaan diri kepada para individu yang terlibat agar mampu melakukan tindakan Pertolongan Pertama sebelum adanya tindakan medis lebih lanjut.

e. Memberikan prinsip-prinsip kemampuan yang langsung dapat dipraktekkan tentang Cardio Pulmonary Resuscitation (CPR).

f. Memfasilitasi individu yang ingin berlatih kemampuan pertolongan pertama dan memperoleh sertifikat.

g. Menghilangkan batasan waktu, jadwal, jarak dan tempat yang menghambat proses pelatihan.

h. Meminimalisir biaya pelatihan langsung yang dibutuhkan.

\subsection{PRINSIP-PRINSIP PELATIHAN PP ONLINE}
a. Prinsip ketergantungan positif (positive interdependence)
b. Tanggung jawab perseorangan (individual accountability)
c. Partisipasi dan komunikasi (participation and communication $)^{[6]}$

\subsection{PENDEKATAN DALAM PELATIHAN PP ONLINE}
a. Pendekatan Konsep
b. Pendekatan Proses
c. Pendekatan Partisipatif ${ }^{[7]}$

\subsection{PERAN PENGAJAR DALAM PELATIHAN PP ONLINE}

Pengajar dalam metode Pelatihan Pertolongan Pertama tidak lagi memberi pembelajaran di kelas, tetapi berperan sebagai : b. Model

Mengadopsi Kurikulum yang sesuai dengan Protocol of International Red Cross dan Asosiasi Jantung Amerika (American Heart Association) dengan pelatihan yang bersertifikat nasional dan internasional. Tim pelatih terdiri dari tenaga dokter ACLS dan ATLS serta pelatih tersertifikasi K3 Umum dari Kementerian Tenaga Kerja dan Transmigrasi.

\subsection{PERAN SISWA DALAM PELATIHAN PP ONLINE}

Siswa berperan dalam pelatihan Pertolongan Pertama online ini sebagai berikut :
a. Merencanakan
b. Menanyakan
c. Mempelajari
d. Mengisi ujian tertulis
e. Membuat video simulasi
f. Mengunggah video
g. Mencetak sertifikat

\subsection{KEUNGGULAN PELATIHAN PP ONLINE}

Keunggulan yang dihasilkan dari pelatihan PP online, merupakan gabungan dari keunggulan oleh mobile learning dan keunggulan dan fitur ini sendiri. Berikut dipaparkan keunggulan dari Pelatihan Pertolongan Pertama online, poin a sampai dengan c merupakan keunggulan mobile learning, sedangkan d hingga i merupakan keunggulan fitur ini :

a. Pelajar tidak terlalu bergantung pada pengajar.

b. membantu memberdayakan seriap siswa untuk lebih bertanggung jawab dalam belajar

c. dapat meningkatkan kemampuan siswa menggunakan informasi dan kemampuan belajar abstrak menjadi nyata $^{[10]}$

d. Pelatihan dapat dilakukan kapan saja dan dimana saja tanpa harus terjadwal.

e. Tidak perlu menunggu kuantitas jumlah peserta tertentu untuk dapat melaksanakan pelatihan.

f. Mengurangi biaya tertentu yang diperlukan apabila melaksanakan pelatihan langsung seperti biaya transportasi, makan, ruang, dll.

g. Akan lebih banyak orang-orang yang terlatih dalam melaksanakan pertolongan pertama sehingga dapat menekan angka kematian ataupun cidera berat.

h. Regulasi dan proses yang lebih mudah dan efisien.

i. Sertifikat dapat dalam bentuk e-certificate.

\subsection{KEUNTUNGAN PESERTA MEMILIKI E- CERTIFICATE}

- Memperoleh pengetahuan mengenai pertolongan pertama yang dapat diimplementasikan dalam kehidupan sehari-hari.

- Menjadi poin positif tersendiri yang dapat dicantumkan dalam daftar riwayat hidup ketika melamar pekerjaan.

- Merupakan syarat tertentu untuk mengikuti organisasi. 
- Menimbulkan rasa percaya diri serta diakui oleh orang banyak atas kemampuan dalam penanganan kegawatdaruratan.

\section{ANALISIS KONSEP DAN PERANCANGAN SISTEM}

\subsection{DESKRIPSI DISAIN PELATIHAN PERTOLONGAN PERTAMA ONLINE}

Berdasarkan kegiatan pengajar dan pelajar dalam pelatihan pertolongan pertama online, maka fitur yang akan dibuat di dalam lingkungan mobile terbagi dalam enam fase tahapan yakni :

1. Menyampaian tujuan

2. Menyajian informasi

3. Pendaftaran diri

4. Pelaksanaan pembelajaran

5. Pelaksanaan ujian

6. Penilaian dan sertifikasi

\subsection{PERMODELAN SISTEM PELATIHAN PP ONLINE}

Berikut adalah skenario dan penjelasan sistem pelatihan pertolongan pertama online ini:

1. Pelajar terlebih dahulu harus memilih paket pelatihan PP yang diinginkan. Terdapat tiga paket pelatihan. Yaitu, pelatihan dasar, pelatihan lanjutan, dan pelatihan mahir.

2. Setelah mengetahui paket yang akan dipilih, pelajar harus mengisi formulir online yang tersedia pada aplikasi tersebut.

3. Selanjutnya, pelajar harus mentransfer sejumlah uang sesuai paket yang dipilih untuk biaya administrasi, materi dan perlengkapan.

4. Pihak PMI akan memproses formulir dan uang yang telah dikirim ke rekening milik PMI.

5. Setelah memastikan uang sudah di transfer sesuai dengan formulir yang diisi. Maka PMI akan mengirim surat konfirmasi dan perlengkapan pertolongan pertama ke pelajar serta memberi akses untuk membuka materi ajar yang berupa video dan tulisan.

6. Pelajar harus mempelajari materi ajar yang telah diberikan.

7. Setelah cukup yakin dengan kemam-puannya, pelajar harus mengikuti ujian tertulis yang merupakan pengembangan dari fitur "ujian" pada aplikasi saat ini.

8. Lalu, pihak PMI akan menilai hasil ujian tertulis tersebut dan menentukan lulus atau tidaknya peserta ujian.

9. Apabila peserta ujian tidak lulus, maka diperkenankan untuk mengulang pembelajaran. Dan apabila pelajar berhasil, maka diperkenankan melanjutkan pada ujian selanjutnya, yaitu dengan mengunggah video simulasi.
10. Simulasi akan dilaksanakan oleh pelajar dengan perlengkapan yang telah dikirim serta fitur tambahan yang tersedia pada aplikasi tersebut. Simulasi tersebut harus di rekam dan diunggah untuk dinilai pihak PMI.

11. PMI menentukan lulus atau tidaknya peserta dalam ujian simulasi. Apabila peserta tidak berhasil, maka peserta diperkenankan mengulang untuk mempelajari materi dan mengulang ujian dari awal.

Apabila peserta berhasil, maka peserta akan menerima sertifikat dalam bentuk e-certificate yang dapat dicetak sendiri.

Berikut adalah diagram alur untuk penjelasan mengenai sistem kerja fitur ini :

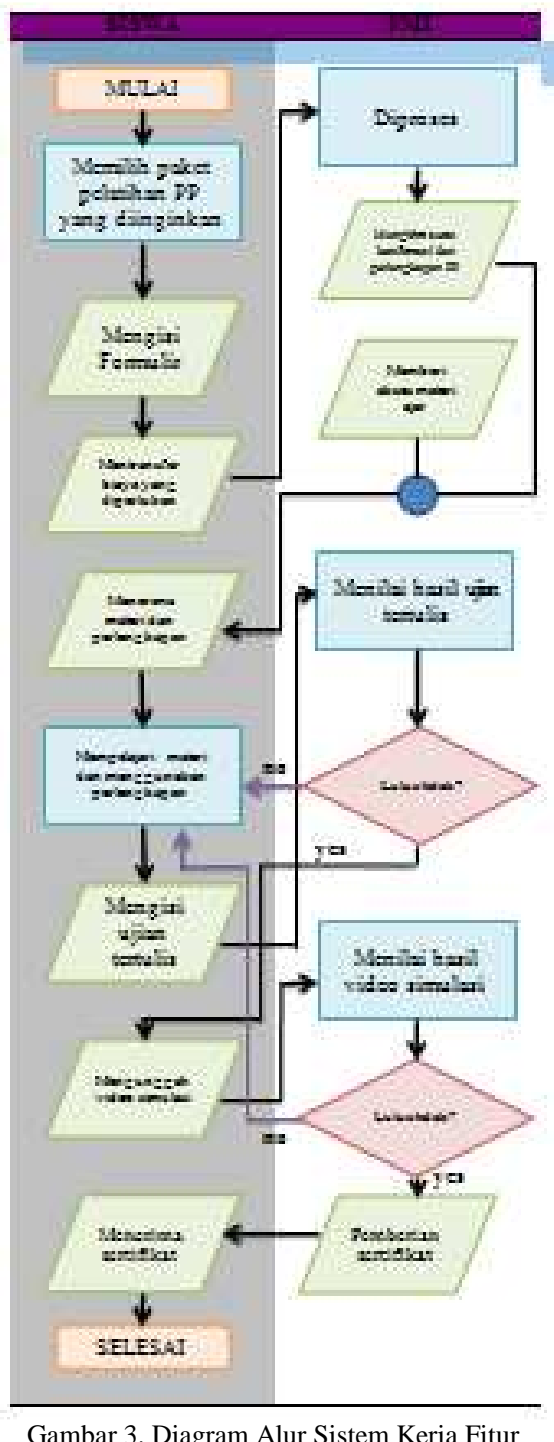

Gambar 3. Diagram Alur Sistem Kerja Fitur 


\subsection{DESKRIPSI DISAIN FITUR}

Disain fitur ini hanya melengkapi aplikasi sebelumnya, tidak ada perubahan yang signifikan dengan adanya fitur ini. Bagian yang ditambahkan yaitu :

- Ujian sertifikasi yang terdiri dari ujian tertulis dan ujian simulasi yang dapat mengunggah video.
- Pelatihan Pertolongan Pertama yang tersedia formulir, akses khusus materi pelatihan pertolongan pertama, PocketCPR untuk membantu simulasi CPR.

Gambaran unsur-unsur tambahan dalam pengembangan aplikasi secara umum digambarkan dalam peta konsep berikut:

PMI FIRST AID

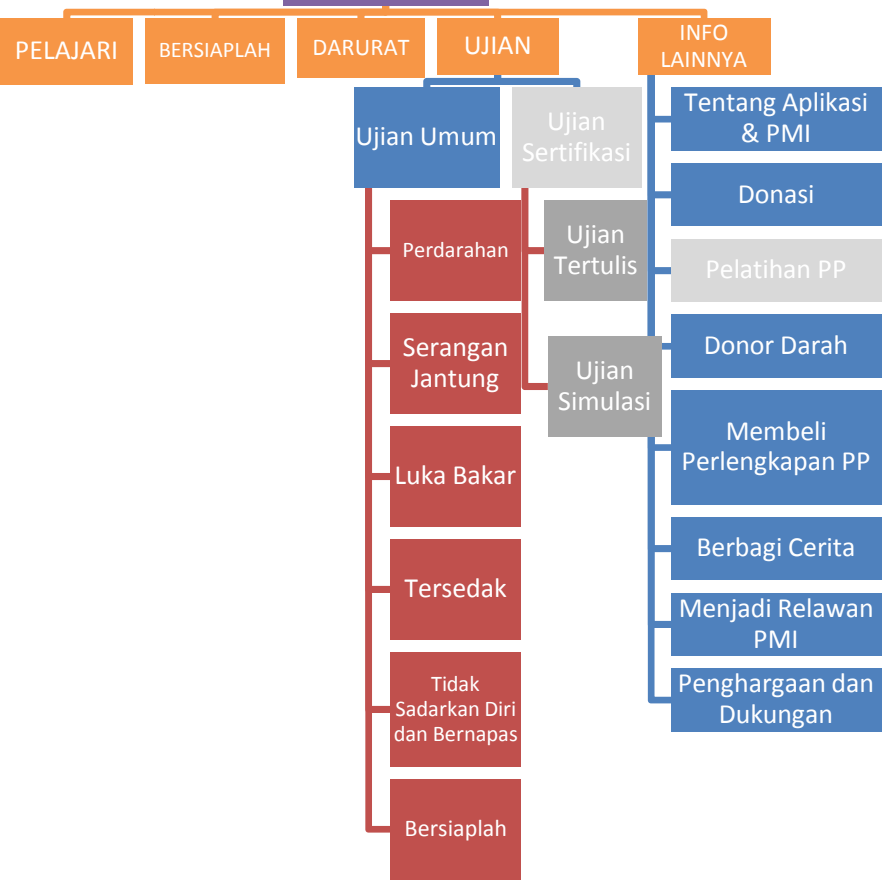

Gambar 4: Diagram Pengembangan Fitur PMI: First Aid Kit

*) Bagian abu-abu merupakan pengembangan fitur
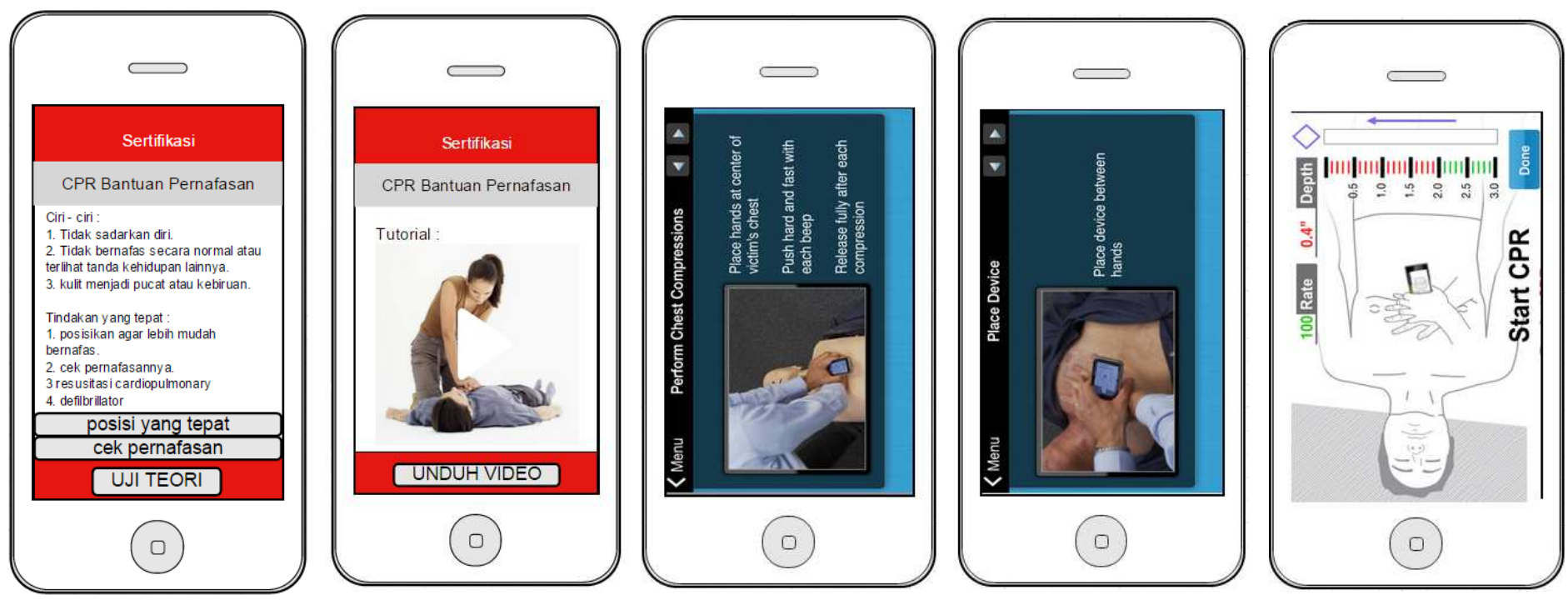

Gambar 3. Rancangan Tampilan Aplikasi 


\subsection{ANALISA KEBUTUHAN SDM}

Orang yang terkait dengan pelatihan dan perannya dalam pelatihan pertolongan pertama online ini dijelaskan pada tabel berikut :

Tabel 2. Peran SDM

\begin{tabular}{|l|l|}
\hline $\begin{array}{c}\text { Orang } \\
\text { Terkait }\end{array}$ & \multicolumn{1}{|c|}{ Peran } \\
\hline Pelajar & - Mengikutipelatihan pertolongan \\
& $\begin{array}{l}\text { - } \text { mertama } \\
\text { disediakan }\end{array}$ \\
& $\begin{array}{l}\text { - mengikuti ujian tertulis dan ujian } \\
\text { simulasi yang disediakan }\end{array}$ \\
& \\
\hline Pengajar & $\begin{array}{l}\text { - Mengatur sumber belajar dan situs } \\
\text { terkait }\end{array}$ \\
& - Menampilkan dan \\
& memperbaharuiinformasipembelajar \\
& an \\
& - Melayanikoreksibagi ujian yang \\
& gagal \\
& - Menilaipelajar \\
& \\
\hline Admin & - Menatafasilitaspembelajaran \\
& - Memproses registrasi \\
& - Mengirim perlengkapan pelatihan \\
& - Melayanibantuanteknis \\
\hline
\end{tabular}

Desain ini memperkaya cara pelatihan dimana pelajar sebagai pusat (student centered learning). Pelajar diharapkan aktif mempelajari materi yang diberikan dan mengikuti ujian secara mandiri. Pengajar hanya sebagai fasilitator dan pemandu dalam proses belajar.

\section{PENUTUP}

\subsection{KESIMPULAN}

Pada penelitian ini disadari bahwa, diperlukan inovasi dalam Pelatihan Pertolongan Pertama. Maka, dibuatlah sebuah konsep Pelatihan Pertolongan Pertama online yang dapat menyelesaikan persoalan jarak dan waktu. Pengembangan ini akan menjadi fitur tambahan dalam aplikasi milik PMI yang telah ada saat ini.
Pengembangan dilakukan sehingga peserta dalam mengakses dimana saja dan kapan saja, selain itu, regulasi pendaftaran menjadi lebih mudah serta efisien. Fitur ini memungkinkan pengguna untuk dapat mengakses materi khusus yang diberikan pihak penyelenggara, mengikuti ujian tertulis secara online, menunggah video simulasi untuk dinilai, dan peserta akan memperoleh e-certificate setelah dinyatakan lulus.

\subsection{SARAN}

Studi ini masih membutuhkan penelitian dan langkah lanjutan, yaitu :

1. Konfirmasi regulasi dan kerja sama dengan pihak PMI

2. Verifikasi user agar tidak terjadi kecurangan tertentu.

3. Pengembangan fitur secara nyata.

\section{REFERENSI}

${ }^{[1]}$ Koulias, M., Leahy, G., Scott, K.M., Phelps, M. \& Campbell, D. 2012. Wherever, whenever, learning in Medicine: Evaluation of an interactive mobile case-based project.Wellington: Proceedings ascilite.

${ }^{[2]}$ Www.virtualcollege.co.uk/eleaning/elearning.asx

${ }^{[3]}$ Woodille, Gary. 2011. Mobile Learning. US: The Mc Graww-Hill Companies

${ }^{[4]}$ Conn, Joseph. 2013. No longer a novelty, medical apps are increasingly valuable to clinicians and patients. Chicago: Crain Communications.

${ }^{[5]}$ Peterson, Ronnie. 2014. Teaching Cardiopulmonary Resuscitation Via the Web. Alisa Veijo: The InnoVision Group.

${ }^{[6]}$ Slavin, Gobert. 1995. Cooperative Learning Theory. Massachusetts: Allyn and Bacon Publisher.

${ }^{[7]}$ Ngalim Purwanto. 2002. Psikologi Pendidikan. Bandung: Remaja Rosda Karya

${ }^{[8]}$ Starr, Larry M. 1997. A New First Aid Training Curriculum. US: 1105 Media, Inc.

${ }^{[9]}$ Goddard, Kara B. 2010. Basic Life Support and Cardiopulmonary Resuscitation Training. Alexandria: American Association of Colleges of Pharmacy.

${ }^{[10]}$ Sonjaya, Iwan dan kawan-kawan. Perancangan Sistem Pembelajaran Berbasis Web dengan Menggunakan Pendekatan Model Cooperative Learning. Bandung: Academia Edu 